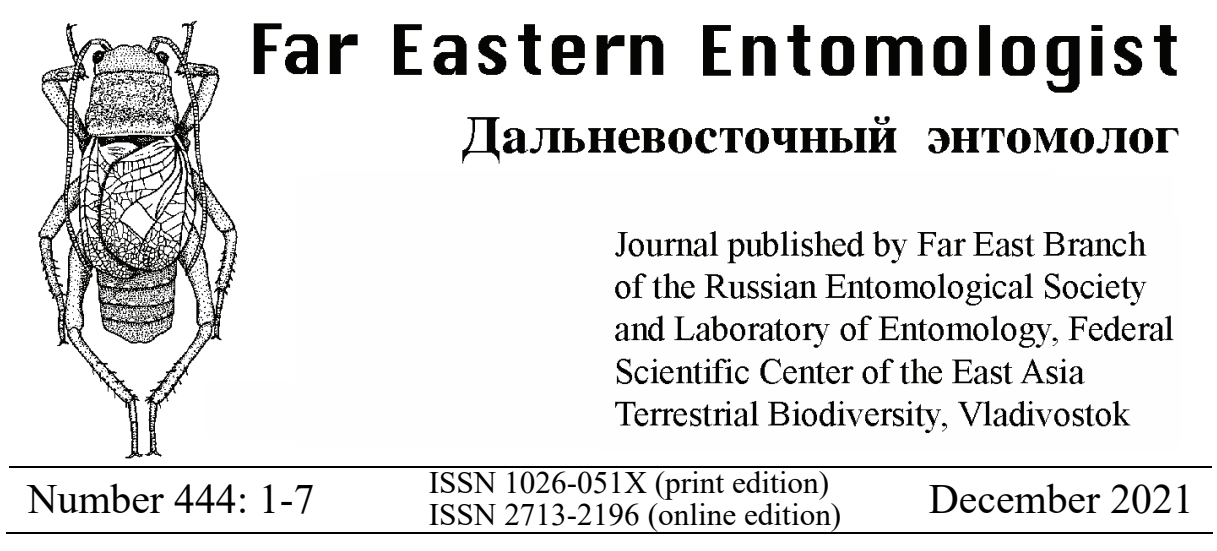

https://doi.org/10.25221/fee.444.1

http://zoobank.org/References/E4DC3D6B-887E-40AF-AB77-C761DFDC068B

\title{
TWO NEW SPECIES OF THE GENUS ARCHAEOPOL YCENTRA (TRICHOPTERA: POLYCENTROPODIDAE) FROM CRETACEOUS TAIMYR AMBER
}

\author{
S. I. Melnitsky, V. D. Ivanov
}

Department of Entomology, Faculty of Biology, St. Petersburg State University, Universitetskaya nab., St. Petersburg 199034, Russia.E-mail: simelnitsky@gmail.com; v--ivanov@yandex.ru

Summary. Two new caddisfly species Archaeopolycentra turvalsia sp. n. and Archaeopolycentra achupomotet sp. n. (Polycentropodidae) from Late Cretaceous Taymyr amber (Santonian, Kheta Formation, $85 \mathrm{Ma}$ ) are described and illustrated. Totally, now the list of caddisflies from Taymyr amber includes 13 species, and the family Polycentropodidae is represented by five species.

Key words: Trichoptera, caddisflies, Polycentropodidae, Archaeopolycentra, taxonomy, new species, paleontology.

А С. И. Мельницкий, В. Д. Иванов. Два новых вида рода Archaeopolycentra (Trichoptera: Polycentropodidae) из мелового таймырского янтаря // Дальневосточный энтомолог. 2021. N 444. С. 1-7.

Резюме. Из раннемелового таймырского янтаря (сантон, хетская свита, 85 млн. лет назад) описаны два новых вида ручейников Archaeopolycentra turvalsia sp. n. и Archaeopolycentra achupomotet sp. n. (Polycentropodidae). C учетом новых видов список ручейников таймырского янтаря включает 13 видов, причем семейство Polycentropodidae представлено 5 видами. 


\section{INTRODUCTION}

The Trichoptera fossils are diverse and abundant in the Cretaceous resins. Sixtythree species of caddisflies found in Alberta, Burmese, Lebanese, New Jersey, Taymyr, and Tennessee Cretaceous ambers. The largest numbers of species are recorded in Burmese amber, 39 species distributed among 10 families (Wichard, 2020; Wang et al., 2021; Wichard et al., 2021).

The family Polycentropodidae is worldwide distributed with over 800 species in recent fauna and includes more than 100 fossil species (Morse 2021). This family has the rich fossil diversity in the Paleogene resins of Europe (Ivanov et al., 2016). Six species of the family Polycentropodidae are found in Cretaceous Burmese and Taymyr ambers (Ivanov \& Melnitsky, 2017; Wichard, 2020). The list of caddisfly species from Taimyr amber includes 11 species from 7 families: Archaeopolycentra zherikhini Botosaneanu et Wichard, 1983, Archaeopolycentra yantardakh Ivanov et Melnitsky, 2017, Holocentropus spurius Botosaneanu et Wichard, 1983 (Polycentropodidae), Taymyrodipseudon protopegasus Ivanov et Melnitsky, 2017 (Dipseudopsidae), Rhyacophila antiquissima Botosaneanu et Wichard, 1983 (Rhyacophilidae), Kliganigadukia taymyrensis Ivanov et Melnitsky, 2017, Palaeohydrobiosis siberambra Botosaneanu et Wichard, 1983 (Hydrobiosidae), Taymyrelectron sukatshevae Botosaneanu et Wichard, 1983 (Taymyrelectronidae), Calamodontus grandaevus Botosaneanu et Wichard, 1983 (Calamoceratidae), Praeathripsodes jantar Botosaneanu et Wichard, 1983, and Siberoclea parapolaria Ivanov et Melnitsky, 2017 (Leptoceridae) (Botosaneanu \& Wichard, 1983; Ivanov \& Melnitsky, 2017). All these species descriptions are based on specimens found during expeditions of the Paleontological Institute of the Russian Academy of Sciences to the Taimyr Peninsula in 1970-2012 (Ivanov \& Melnitsky, 2017). This material was supposed to be Santonian, 83-87 Ma, Kheta formation (Zherikhin, 1978). The Yantardakh locality is richest of the Kheta formation, with nearly 6000 inclusions (Perkovsky \& Makarkin, 2015). We describe here two new species from the fossil genus Archaeopolycentra from the Yantardakh locality.

\section{MATERIAL AND METHODS}

The material was found in summer of 2012 at the locality Yantardakh (East Taymyr, Khatanga Depression, Krasnoyarsk region, Russia) by paleoentomologists D. S. Kopylov and E.A. Sidorchuk accompanied by D. D. Vorontsov. The amber deposits were found on the right bank of the Maimecha River (71 18 ' $27^{\prime \prime}$ N; $99^{\circ}$ $33^{\prime} 47^{\prime \prime}$ E) at Yantardakh Hill, with the bank cliffs spread about $200 \mathrm{~m}$ long and up to $15 \mathrm{~m}$ high. The types are deposited in Borissiak Paleontological Institute (Moscow, Russia) collection of insects.

The study of these fossils was accomplished with Nikon SMZ1500 microscope provided with Nikon D700 and Canon Powershot A640 cameras. Photographs have been postprocessed with graphics software to reveal details of the structures. We have used the conventional methods for studying the insects in ambers (Rasnitsyn \& 
Quicke, 2002). In this paper, we use the interpretation of genital structures of genus Archaeopolycentra previously proposed by the authors (Ivanov \& Melnitsky, 2017).

\section{TAXONOMY}

Order Trichoptera Kirby, 1813

Suborder Annulipalpia Martynov, 1924

Family Polycentropodidae Ulmer, 1903

Genus Archaeopolycentra Botosaneanu et Wichard, 1983

\section{Archaeopolycentra turvalsia Melnitsky et Ivanov, sp. $\mathbf{n}$.}

http://zoobank.org/NomenclaturalActs/216E2B54-0BBC-4A08-8534-543ED821CDAE

Figs 1-3

TYPE MATERIAL. Holotype: $\widehat{\jmath}$, PIN 3311/1861, Russia: Taymyr amber, Yantardakh, $3 \mathrm{~km}$ above the mouth of Maimecha river, Eastern Taymyr, Kheta formation, Santonian. Head and thorax are absent in this type specimen.

DESCRIPTION. Legs and abdomen yellowish. Wings light brown.
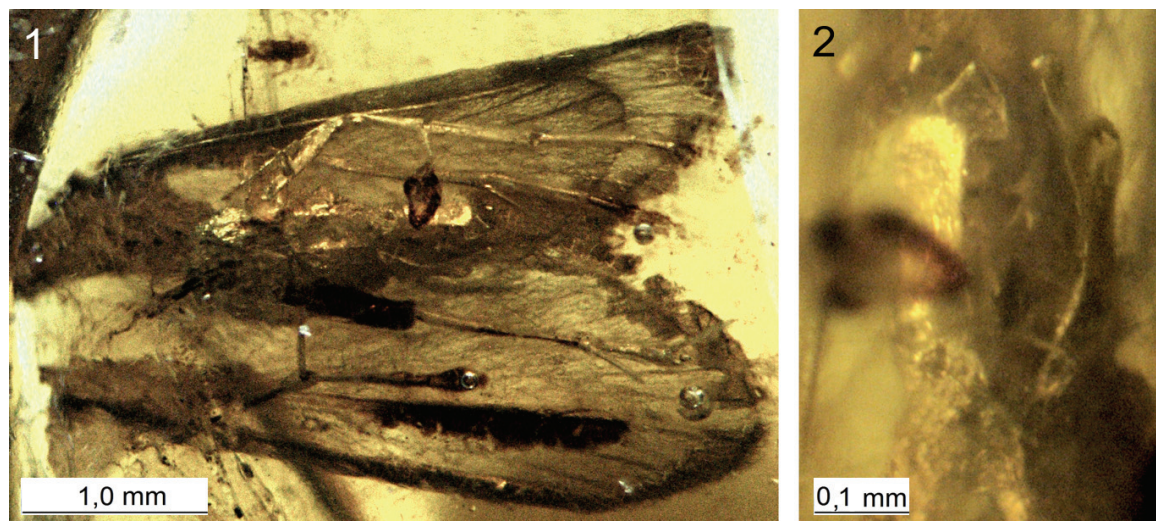

Figs 1, 2. Archaeopolycentra turvalsia sp. n. (holotype, male): 1 - general view, ventral; 2 - genitalia, ventral.

Male genitalia. Posterioventral margin of sternite IX without tubercles, projected posteriorly as a rounded plate. Projections of the segment $\mathrm{X}$ longer than aedeagus, with thin lamellar leaf-like curved apex. Inferior appendages are long and apparently represented by wide ventral lobes; their dorsal lobes, if present, should be small, although they are not clearly visible. Apex of ventral lobe with thin pilosity and 2 long yellowish setae seen on the left gonopod. Aedeagus pentagonal in crosssection, sclerotized around its perimeter. Distal part of aedeagus with 2 long bonelike downward directed lateral processes wide in apical parts. 
MEASUREMENTS. Body length $2.1 \mathrm{~mm}$; forewing length $2.7 \mathrm{~mm}$.

DIAGNOSIS. The new species is related to †Archaeopolycentra zherikhini Botosaneanu et Wichard, 1983 and A. achupomotet sp. n. from the same locality. The new species differs from the former one in the shape of the apex of the aedeagus and in the presence of long processes in the medial part of the aedeagus, and from the latter species in the shorter dorsal lobe of the gonopod and the longer processes of the aedeagus. One more species of this genus, Archaeopolycentra yantardakh Ivanov et Melnitsky, 2017, is more remote because of smaller lateral processes of aedaegus and shorter projections of segment $\mathrm{X}$.

ETYMOLOGY. Arbitrary combination of letters.

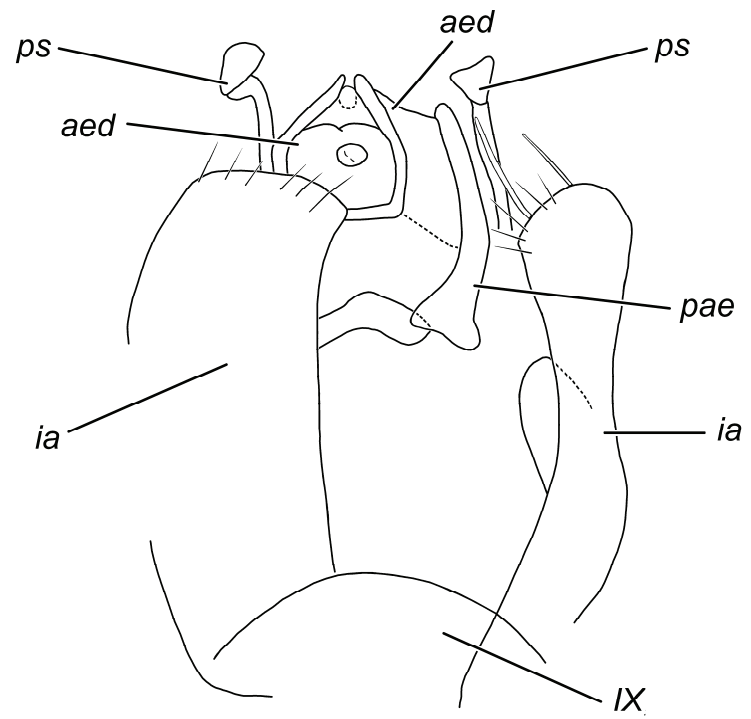

Fig. 3. Archaeopolycentra turvalsia sp. n. (holotype, male): genitalia, ventral. Abbreviations: IX - segment IX; aed - aedeagus, $i a$ - inferior appendages, $p s$ - projections of the segment X, pae-lateral processes of aedeagus.

\section{Archaeopolycentra achupomotet Melnitsky et Ivanov, sp. n.}

http://zoobank.org/NomenclaturalActs/41F1A48A-DC63-407A-A311-D810A3BA7C81

Figs 4-6

TYPE MATERIAL. Holotype: $\widehat{\jmath}$, PIN 3311/2871, Russia: Taymyr amber, Yantardakh, $3 \mathrm{~km}$ above the mouth of Maimecha river, Eastern Taymyr. Kheta formation, Santonian.

DESCRIPTION. Head, antennae and palpi yellowish brown. Legs, abdomen, thorax and wings light brown. Antennae shorter than forewings, light brownishyellowish. Wings with long dark hairs obscuring the wing venation. 
Male genitalia. Posteroventral margin of sternite IX with 2 tubercles. Projections of the segment $\mathrm{X}$ long, with complex bending in the subapical part and truncate sides of triangular apical plates, equal in length to the aedeagus. Inferior appendages (gonopods) hairy, wide with deep incision separated them into longer and narrower dorsal lobe, and shorter and wider ventral lobe. Apices of the gonopod lobes pointed in the ventral view. External surfaces of gonopods covered with numerous hairs. Aedeagus large, rounded at apex with two sclerites in the ventral view. Distal part of aedeagus with 2 long clavate downward directed lateral processes.
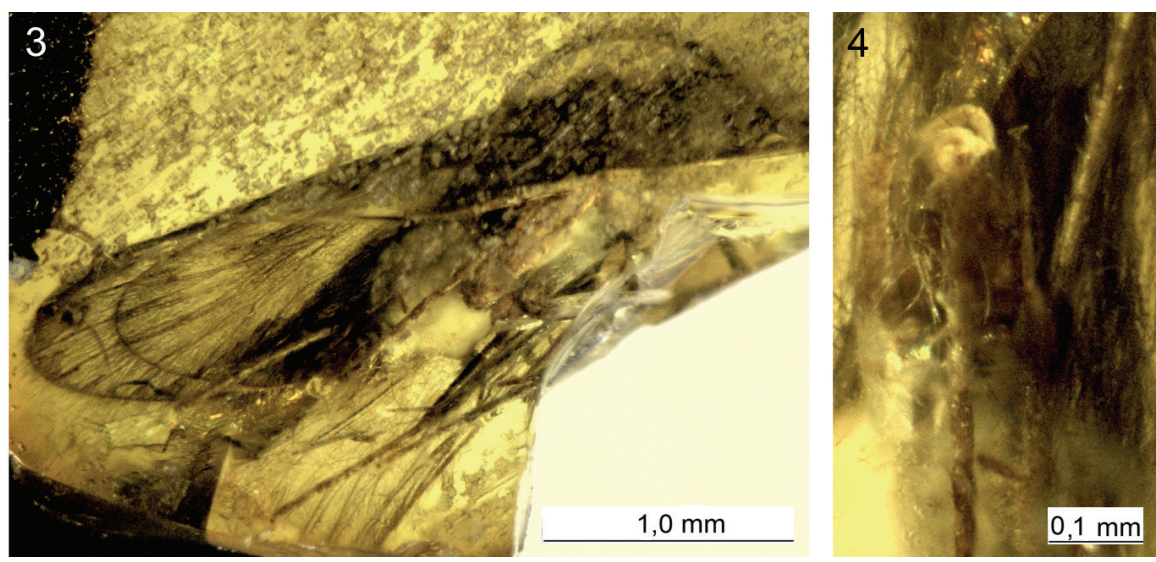

Figs 4, 5. Archaeopolycentra achupomotet sp. n. (holotype, male): 4 - general view, ventral; 5 - genitalia.

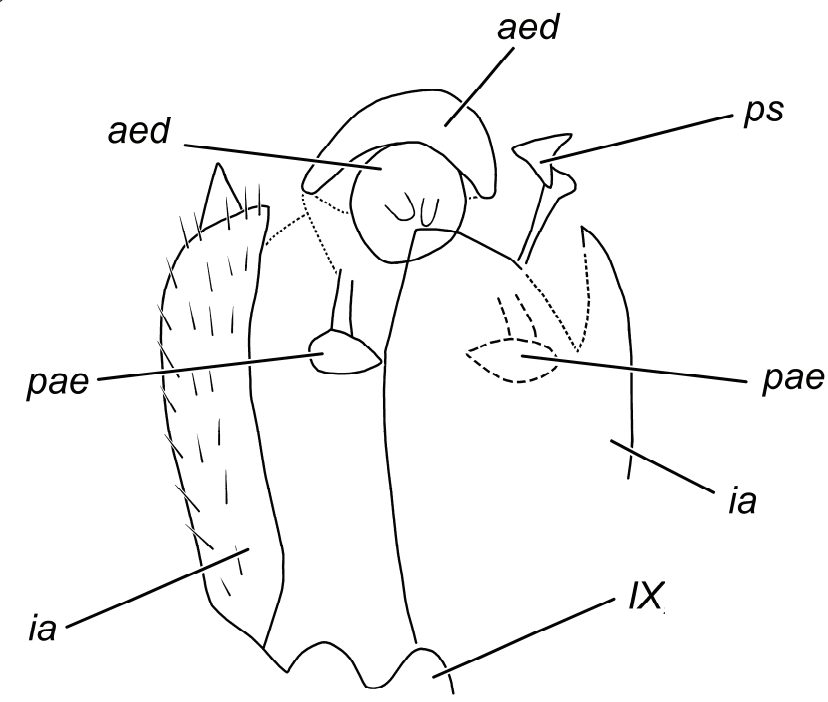

Fig. 6. Archaeopolycentra achupomotet sp. n. (holotype, male): genitalia, ventral. Abbreviations as in Fig. 3 
MEASUREMENTS. Body length $2.3 \mathrm{~mm}$; forewing length $3.0 \mathrm{~mm}$.

DIAGNOSIS. The new species is related to Archaeopolycentra zherikhini Botosaneanu et Wichard, 1983 and Archaeopolycentra yantardakh Ivanov et Melnitsky, 2017 from the same locality. The diagnostic characters are the different shape of the inferior appendages: the dorsal lobe is equal to ventral in the new species and in A. yantardakh, and shorter in A. zherikhini; the incision of these appendages is very deep in $A$. yantardakh while in the new species and in $A$. zherikhini it is more shallow. The shape of the aedeagal clavate processes is also characteristic for the new species: they are long in the new species with sclerotized widened apex, non-visible in A. zherikhini, and short and apically pointed in $A$. yantardakh. The shape of projections of segment $\mathrm{X}$ is suggestive; in A. zherikhini, the projections of segment $X$ are uniformly narrow with a small hook at apex, short and almost straight in A. yantardakh and long with apical hook and triangular apex in the new species. This species differs from the above described $A$. achupomotet sp. $n$. in the shape of inferior appendages, apical parts of projections of segment $\mathrm{X}$, and in configuration of the lateral processes of aedeagus.

ETYMOLOGY. Arbitrary combination of letters.

\section{DISCUSSION}

The new species described here are among the smallest known for the family Polycentropodidae. The tiny specimens are similar in size to the microcaddisflies from the family Hydroptilidae and Xiphocentronidae, and smallest Psychomyiidae of the genus Paduniella but do not show the characteristic changes in genitalia, wing venation and wing shape known for small insects. The wing venation in species of the genus Archaeopolycentra is not reduced; wings are rather wide with rounded apex. The genitalia of Archaeopolycentra are comparable in complexity with other Polycentropodidae and do not show reductions typical for the smallest Trichoptera. There could be larger polycentropodid species in the fossil Taymyr fauna but the form of preservation in small resin pieces is not suitable for larger specimens. Addition of two new Polycentropodidae species raises the presence of this family in the Taimyr Trichoptera to $38 \%$ of species. This share is comparable to the diversity of this family in the younger faunas of Baltic and Rovno amber (Ivanov et al., 2016). The list of Taymyr amber caddisflies includes now 13 species, and the family Polycentropodidae is represented by five species from two genera.

\section{ACKNOWLEDGEMENTS}

We are grateful to colleagues in the Paleontological Institute of Russian Academy of Sciences (Moscow) for amber collecting and the treatment of amber. Special thanks are due to late Ekaterina Sidorchuk for careful polishing of the tiny amber fragments. 


\section{REFERENCES}

Botosaneanu, L. \& Wichard, W. 1983. Upper cretaceous Siberian and Canadian amber caddisflies (Insecta: Trichoptera). Bijdragen tot de dierkunde, 53: 187-217.

Ivanov, V.D., Melnitsky, S.I. \& Perkovsky, E.E. 2016. Caddisflies from Cenozoic resins of Europe. Paleontological Journal, 50 (5): 485-493. DOI: https://doi.org/10.1134/ S0031030116050063

Ivanov, V.D. \& Melnitsky, S.I. 2017. New caddisflies species (Insecta: Trichoptera) from the Cretaceous Taymyr amber. Cretaceous Research, 77: 124-132. DOI: https://doi.org/ 10.1016/j.cretres.2017.04.009

Morse, J.C. (Ed.) 2021. Trichoptera World Checklist. Available online at http://entweb. clemson.edu/database/trichopt/index.htm [Accessed 18 November 2021].

Perkovsky, E.E. \& Makarkin, V.N. 2015. First confirmation of spongillaflies (Neuroptera: Sisyridae) from the Cretaceous. Cretaceous Research, 56: 363-371. DOI: https://doi.org/ 10.1016/j.cretres.2015.06.003

Rasnitsyn, A.P. \& Quicke, D. (Eds.) 2002. History of Insects. Kluwer Academic Publishers. Dordrecht, Boston, London. 518 pp. DOI: http://dx.doi.org/10.1007/0-306-47577-4

Wichard, W. 2020. Overview of the caddisflies (Insecta, Trichoptera) in mid-Cretaceous Burmese amber. Cretaceous Research, 119: 104707. DOI: https://doi.org/10.1016/ j.cretres.2020.104707

Wichard, W., Müller, P. \& Xu, C.P. 2021. The odontocerid genera Psilotreta and Palaeopsilotreta (Insecta, Trichoptera) embedded in mid-Cretaceous Burmese amber. Palaeoentomology, 4 (4): 331-338. DOI: https://doi.org/10.11646/palaeoentomology.4.4.8.

Wang, J., Zhang, W., Shih, C. \& Ren, D. 2021. Two new mid-Cretaceous caddisflies (Trichoptera, Philopotamidae) from amber of Northern Myanmar. Cretaceous Research, 126: 104891. DOI: https://doi.org/10.1016/j.cretres.2021.104891.

Zherikhin, V.V. 1978. Development and Changes in Cretaceous and Cenozoic Faunistic Complexes (Tracheates and Chelicerates). Nauka Press, Moscow. 200 pp. [In Russian] 